
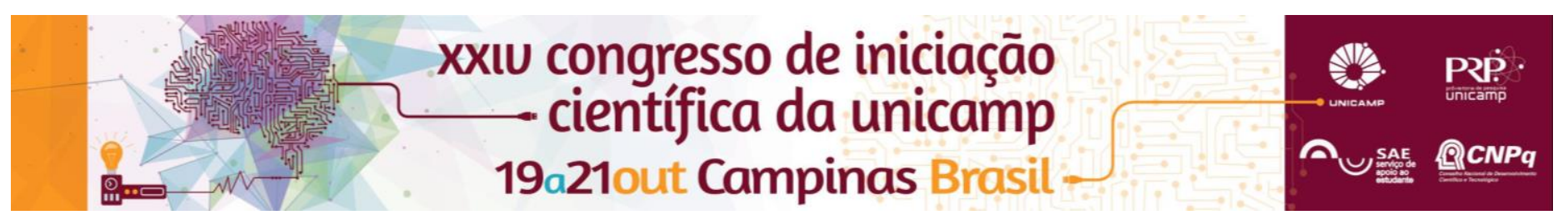

\title{
Estriamento por Esgotamento, Coloração de Gram e PCR
}

\author{
Milena Oliveira dos Santos*, Júlia Letícia de Pádua Francisco*, Lucas Henrique Martins Abou Khezam*, \\ Leonardo Cardoso Alves, Vinícius de Oliveira Almeida, Sandra de Almeida Queiroz, Rafael Soares Correa de \\ Souza, Jaderson Silveira Leite Armanhi, Paulo Arruda
}

\section{Resumo}

A técnica de esgotamento por estriamento visa diminuir a população microbiana por via do método de estriamento, facilitando assim o isolamento de microorganismos por permitir a formação de colônias puras no meio de cultura sólido escolhido. A coloração de Gram é uma técnica de coloração para diferenciação de microrganismos através das cores, a partir da composição de suas paredes celulares. PCR (reação em cadeia da polimerase) é uma técnica muito utilizada para a replicação da fita de DNA em laboratório.

\section{Palavras-chave: \\ Estriamento; Gram; PCR.}

\section{Introdução}

O método de estriamento por esgotamento em placa com meio sólido permite a obtenção de colônias formadas a partir de uma única unidade formadora de colônia. A coloração das células é determinada a partir da composição de sua parede celular. A reação em cadeia da polimerase (PCR) é um método que permite a amplificação de um fragmento específico de DNA, como um gene. A técnica utiliza uma pequena quantidade de DNA e se baseia na amplificação desse fragmento específico até um elevado número cópias.

\section{Resultados e Discussão}

O estriamento resulta na obtenção de colônias isoladas. Para isso, é importante trabalhar numa área esterilizada, mantendo todo material sempre livre de contaminações. Deve se manter atenção para não cruzar as estrias, de modo a garantir a redução do inóculo a cada estria, e a se obter colônias isoladas.
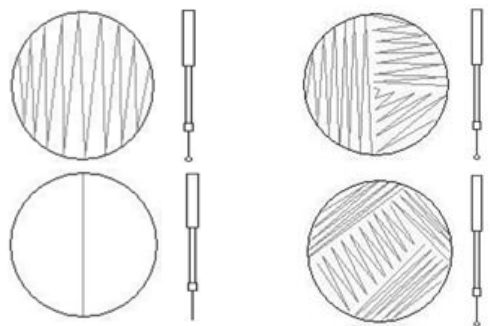

Figura 1. À esquerda, demonstração de uma estria simples. À direita, demonstração de esgotamento em estrias ou estrias múltiplas.

Após uma semana de crescimento bacteriano, os testes de coloração foram feitos com as colônias crescidas. Utilizamos os corantes cristal violeta, lugol e fucsina. A parede celular das bactérias Gram-negativas tem um teor em lipídios elevado na sua membrana externa, e uma camada fina de peptidoglicano que circunda a membrana plasmática.

Neste trabalho foram identificadas bactérias Gramnegativas e Gram-positivas, resultados esperados devido à ampla variedade de microorganismos presentes no solo.

\section{Conclusões}

As reações de amplificação do gene $16 \mathrm{~S}$ foram feitas a partir das colônias de bactérias que cresceram no meio de cultura. Para a validação da amplificação foi usada a técnica de eletroforese em gel de agarose, sendo possível de observar os fragmentos de DNA amplificado a partir da exposição do gel em luz ultravioleta.

\section{Conclusões}

A técnica de estriamento é fundamental para o isolamento de organismos. Pode ser realizada facilmente, e seguindo cuidadosamente os passos de esterilização e estriamento é possível observar e descrever os aspectos e estruturas das colônias isoladas pelo comportamento das mesmas no meio de cultura, seja um meio seletivo ou não-seletivo.

Como existe uma variedade enorme de espécies de bactérias no solo, sendo assim, era esperado encontrar tanto bactérias Gram-positivas quanto Gram-negativas nos testes realizados.

\section{Agradecimentos}

Agradecimentos a todos que me apoiaram, orientaram e ajudaram durante o tempo do curso. Agradeço aos pesquisadores e família por essa caminhada até aqui, rumo à universidade.

\section{Figura 1. Disponível em: <http://lh5.ggpht.com/ 4B9cLTMFtVE/UFOgUoXn_HI/AAAAAAAAKCE/TxbUBBZUgZg/image\% 25255B27\%25255D.png?imgmax=800>. Acesso em: 28 jun. 2016.}

Figura 2. Disponível em: <http://lh3.ggpht.com/RmM2iiyL_88/UFOgVIR3qPI/AAAAAAAAKCM/FG1X5r3tyu4/image\% 252 55B40\%25255D.png?imgmax $=800>$.

Biomedicina Padrão, Técnicas de Semeadura. Disponível em: <http://www.biomedicinapadrao.com.br/2012/09/tecnicas-de-

semeadura.html>. Acesso em: 28 jun. 2016.

Bacilos na Sopa, Método do Estriamento em Placa \& Estriamento em Placa. Disponível em: <https://bacilosnasopa.wordpress.com/tag/tecnica-doestriamento/>. Acesso em: 28 jun. 2016

Ebah, Isolamento de Bactérias pela Técnica de Esgotamento por Estrias e Obtenção de Cultura Pura. Disponível em: <http://www.ebah.com.br/content/ABAAAgvwIAI/isolamento-bacterias-pelatecnica-esgotamento-por-estrias-obtencao-cultura-pura>. Acesso em: 28 jun. 2016.

Micróbios Amigos, Técnica de Esgotamento. Disponível em: $<$ http://microbiosamigos.blogspot.com.br/2007/09/tcnica-deesgotamento.html>. Acesso em: 28 jun. 2016. 